\title{
СУЧАСНІ ПРОБЛЕМИ ПІДГОТОВКИ ЛІКАРІВ НА ЕТАПІ ПІСЛЯДИПЛОМНОЇ ОСВІТИ
}

Е. В. Олійник

Буковинський держсавний медичний університет, м. Чернівиі

\section{THE MODERN PROBLEMS OF PREPARATION OF PHYSICIANS DURING POST-GRADUATE EDUCATION}

\author{
Bukovynian State Medical University, Chernivtsi
}

E. V. Oliynyk

\begin{abstract}
Для України, яка зараз затверджус себе в якості незалежної та рівноправної держави, наявність повноцінної сучасної системи післядипломної медичної освіти, що буде визнана світовим співтовариством, с життєвою необхідністю. Необхідно відмітити, що організація підготовки спеціалістів на етапі післядипломної освіти має суттєві відмінності, які обумовлені, перш за все, нетривалим періодом навчання, багатоканальністю інформації, що потребує її концентрації і адаптації до професійних потреб, необхідністю навиків використання сучасних інформаційних і телекомунікаційних технологій у щоденній професійній роботі.
\end{abstract}

For Ukraine which presently asserts itself as an independent and equal in rights country, the presence of the reliable modern system of post-graduate medical education which will be acknowledged by the world community is a vital necessity. It is necessary to mark, that the organization of preparation of specialists during post-graduate education has substantial differences which are primarily due to the of short duration of studies, multipathing of information, which requires concentration and adaptation to the professional requirements, by the necessity of skills to use the modern information and telecommunication technologies for everyday professional job.

Вступ. Навчання лікаря-інтерна нерозривно пов’язане $з$ якістю підготовки студента у вищому навчальному закладі: чим якісніша вузівська підготовка, тим кращі фахові можливості у лікаря-інтерна. Знання студента і лікаря не завжди ідентичні. Нерідко середній студент стає хорошим лікарем і гірше, якщо навпаки - коли диплом з відзнакою є самоціллю, а не критерієм дійсних знань. Для підвищення мотивації до навчання на післядипломному етапі та полегшення отримання знань необхідно використовувати сучасні інформаційні технології: комп’ютерне забезпечення діагностичного процесу, навчальні відеофільми, мультимедійне забезпечення навчальних програм, електронні рисунки, сучасні тренажери, фантоми, Інтернет та ін. В навчальні програми 3 метою розширення теоретичних знань та набуття практичних навичок необхідно включати відеофрагменти складних клінічних випадків, унікальних хірургічних втручань (схеми 3 коментарями). Така наочність у засвоєнні знань і навичок формує у лікарів-інтернів сучасні концепції, стимулює творче мислення.

Основна частина. Навчальна робота на кафедрі онкології та медичної радіології включає підготовку лікарів-інтернів за спеціальністю “Онкологія”, прове- дення передатестаційних та тематичних циклів удосконалення для лікарів-онкологів.

Проведення передатестаційних циклів стало обов'язковим видом підготовки спеціалістів перед черговою атестацією на лікарську кваліфікаційну категорію. За період навчання курсанти працюють у медичній бібліотеці університету, готують реферати із запланованих тем, складають індивідуальну картотеку із онкологічних захворювань. Курсанти мають змогу користуватися комп'ютерною базою кафедри, що містить лекції з онкології, матеріали з'їздів, конференцій, стандарти діагностики та лікування онкологічних захворювань. Крім семінарських занять, на лекціях використовуються мультимедійні презентації для демонстрації тих онкологічних захворювань, які неможливо продемонструвати на даний час у клініці за відсутності хворих. Це навчання закінчується складанням уніфікованого тестового екзамену й оцінкою вмінь та оволодіння професійними практичними навичками на відповідність певній лікарській кваліфікаційній категорії.

Новим етапом у післядипломній підготовці стало проведення курсів тематичного вдосконалення лікарів. Тематика вдосконалення враховує сучасні

(c) Е. В. Олійник 
актуальні питання надання онкологічної допомоги мешканцям міста та області, з виконанням випускних робіт кожним курсантом та впровадженням їх у лікувально-профілактичних закладах області. Упродовж усіх циклів тематичного удосконалення згідно 3 принципами доказової медицини курсанти навчаються методів сучасної лабораторної діагностики, та дають оцінку сучасним методам обстеження. Усе це дає змогу ефективно проводити контроль засвоєння знань та практичних навичок, підвищити зацікавленість керівників лікувально-профілактичних закладів в участі лікарів на курсах. 3 метою поліпшення діагностики та лікування передракових захворювань жіночої статевої сфери, освоєння скринінгових методів діагностики для лікарів акушерів-гінекологів та сімейних лікарів запроваджено цикл тематичного удосконалення “Діагностика та лікування передпухлинних захворювань та злоякісних пухлин жіночої статевої сфери з основами кольпоскопії.

Як один із методів індивідуального навчання інтернів за спеціальністю “Онкологія” нами запроваджено проведення науково-практичних конференцій із найважливіших питань діагностики, лікування і профілактики онкологічних захворювань. Тематика конференцій визначається календарно-тематичними планами, рекомендаціями викладачів та практикуючих лікарів відділень, які є клінічними базами кафедри, власними побажаннями інтернів. Для участі в науково-практичній конференції лікарі-інтерни готують реферати. Для кожного доповідача призначають рецензента з викладачів кафедри. Інтерни в процесі підготовки доповіді самостійно працюють над літературою, узагальнюють професійні навики при огляді пацієнтів. Такий шлях навчання допомагає їм не тільки знайти необхідну інформацію, але і зуміти іiі проаналізувати, висловити свою думку, навчитися вислуховувати іншу точку зору, та завжди бути готовим до дискусіі.

Беручи до уваги сучасні вимоги, колективом кафедри вибудована система підготовки лікаря. На

\footnotetext{
Література

1. Братусь В. Д. Шляхи інтеграції медичних університетів у систему медичної освіти країн Заходу / В. Д. Братусь, П. Д. Фомін // Журнал сучасного лікаря. Мистецтво лікування. -2003 . - № 6. - С. 23-40.

2. Казаков В. М. Новітні тенденції розвитку європейської
}

першому місці повинні бути клініка, хворий і тільки потім дані лабораторно-інструментальних методів. Сучасні методи дослідження не повинні заміняти клінічного мислення. На сьогодні ще не існує ефективних клініко-діагностичних комп'ютерних програм.

У навчальному процесі викладачами кафедри використовується величезний арсенал засобів для глибокого опанування лікарями-інтернами як теоретичних знань, так і практичних навичок (записані відеофільми для самостійної підготовки, підготовлені навчальнометодичні програми згідно з вимогами Болонського процесу, навчальні кімнати укомплектовані сучасними комп'ютерами). Семінарські заняття проводяться $з$ використанням мультимедійного проектора шляхом слайдових презентацій. Більш глибокому вивченню предмета сприяє складання ними ситуаційних завдань, тестів відповідно до теми заняття.

Інтерни беруть участь у лікувальному процесі, який включає участь в обходах, клінічних розборах, діагностичних маніпуляціях, перев'язках, оперативних втручаннях, патологоанатомічних конференціях.

Висновки. Підсумовуючи наведене вище, ми хочемо підкреслити, що крім позитивних моментів у процесі викладання предмета виникають і деякі проблеми:

а) відсутність університетських клінік та центрів;

б) відсутність сучасної діагностичної та лікувальної апаратури для навчання фахівців, що приводить до необхідності навчання їх за межами кафедри, а іноді і України;

в) недостатня підготовка із суміжних дисциплін у 3в'язку з невеликою кількістю навчальних годин;

г) відсутність можливості відпрацювання деяких діагностичних маніпуляцій та оперативних прийомів на тваринах та на трупах у патологоанатомічних відділеннях в результаті нових положень з біоетики;

д) відсутність можливостей молодим фахівцям брати активну участь у лікувальному процесі та оперативних втручаннях, пов' язаних з умовами жорсткої конкуренції.

медичної освіти / В. М. Казаков, О. М. Талалаєнко, М. Б. Первак// Медична освіта. - 2009. - № 2. - С. 30-44.

3. Вища освіта України і Болонський процес : навч. посіб. / за ред. В. Г. Кременя. - Київ-Тернопіль : Богдан, 2004. -368 c. 